\title{
Effect of Fish Sarcoplasmic Protein on Quality Attributes of No-fat Chicken Sausages Mediated by Microbial Transglutaminase
}

\author{
Bung-Orn Hemung ${ }^{1}$ and Koo Bok Chin* \\ Department of Animal Science and Functional Food Research Institute, College of Agriculture and Life Science, \\ Chonnam National University, Gwangju 500-757, Korea \\ ${ }^{I}$ Faculty of Applied Science and Engineering, Khon Kaen University, Nong Khai Campus, Nong Khai 43000, Thailand
}

\begin{abstract}
Fish sarcoplasmic protein (SP) obtaining from lyophilization was evaluated its effect on the qualities of the no-fat chicken sausages in the presence of microbial transglutaminase (MTG) as compared to sodium tripolyphosphate (STPP). The cooking yields of all sausage samples were not different. Expressible moisture (EM) of sausage samples was reduced by adding fish SP, while the lowest EM values were observed in sausage samples containing STPP. The $\mathrm{pH}$ values of sausage samples were increased with the addition of fish SP and STPP. Proximate analysis revealed that the moisture, fat, and protein contents of all samples were not different ( $p>0.05)$. Textural properties (TP), measured by texture profile analysis, showed that hardness of no-fat sausages increased upon adding fish SP. However, the highest TP values were found in sausage samples with STPP. The redness values were reduced in sausage samples with STPP, while other color values were not affected by STPP. Sensory evaluation revealed that sausages with fish SP were accepted at the higher level than that of control. However, sausage samples with STPP showed highest TP and acceptability. Thus, partial substitution of STPP by SP would be possible to reduce phosphate level in the chicken sausages.
\end{abstract}

Key words: fish sarcoplasmic protein, quality attributes, no-fat chicken sausages, microbial transglutaminase

Received October 11, 2014 / Accepted March 7, 2015

\section{Introduction}

Chicken is an important raw meat for manufacturing sausages, which is oil in protein-water emulsion gel originally made from pork. Currently, an increasing awareness of health led the consumers to consume sausages containing no-fat content without affecting the overall perception. Low-fat protein gel has been developed successfully in the bologna model (Chin et al., 1999). However, no-fat sausages have not been thoroughly investigated in chicken model. The qualities of low-fat sausage have been improved by addition of cross-linking enzyme, microbial transglutaminase (MTG). MTG is derived from Streptoverticillium spp. and currently available as a commercial enzyme (Ando et al., 1989). It catalyzes the formation of the isopeptide bond ( $\varepsilon$-( $\gamma$-glutamyl)lysine) by the acyl transfer reaction of the glutamine-

\footnotetext{
*Corresponding author: Koo Bok Chin, Department of Animal Science and Functional Food Research Institute, College of Agriculture and Life Science, Chonnam National University, Gwangju 500-757, Korea. Tel: +82-62-530-2121, Fax: +82-62530-2129, E-mail: kbchin@jnu.ac.kr
}

bound proteins to the lysine-bound proteins (Folk, 1980). Cross-linking of chicken proteins by MTG was also studied (Ahhmed et al., 2009). MTG improved textural properties of chicken sausages (Ahhmed et al., 2007). However, high cooking loss of protein gel was found after adding MTG (Hong and Chin, 2010). Fortunately, addition of non-meat protein ingredients e.g., soy protein isolate (SPI) and milk proteins could overcome this inferior effects in protein gel (Pietrasik et al., 2007; Ramirez-Suarez and Xiong, 2003).

Yongsawatdigul and Hemung (2010) observed the alternative non-meat protein ingredient, fish sarcoplasmic protein (SP), generating from fish processing plants. However, it is normally washed out during the surimi production since it tends to induce the deterioration of MP in surimi. Therefore, a huge volume of washed water is drained out as a waste, although fish proteins are high nutritive ingredients, water soluble proteins. Lin et al. (1995) reported that $1.7 \mathrm{~kg}$ of SP was recovered from every $100 \mathrm{~kg}$ of surimi production. The recovered SP showed the valuable functional properties e.g., water holding ability and gel enhancing ability (Jafarpour and Gorczyca, 2009). Applying SP powder as an additive in the 
surimi-based products, kamaboko gel, resulted in the negative effect on the color, particularly decreases of whiteness (Kim et al., 2005). Somehow, interactions between SP and MP reduced the gel characteristics, resulting in a reduction of textural properties of fish protein gel (Go and Hwang, 1995). The breaking forces of MTG-mediated MP gel from red sea bream was also reduced due to the high thermal stability upon adding its SP (Hemung and Chin, 2013). Thus, application of recovered SP from surimi plants seemed to be limited for surimi-based products. However, Hemung and Chin (2014) applied the recovered SP into chicken MP resulted in a reduction of thermal stability of protein mixture and an increase of the breaking strength. Thus, the interactions between SP and MP were varied from species to species. Therefore, application of fish SP as the alternative ingredient in no-fat sausages using chicken would be possible. Thus, the objective of this study was to investigate the effect of fish SP on the properties of chicken sausage mediated by MTG in the no-fat model sausages as compared to those with STPP.

\section{Material and Methods}

\section{Materials}

Red sea bream (Pagrus major) samples ( $\approx 1 \mathrm{~kg}$ per each) were catched from Gunnae-ri, Dolsan-eup, Yeosu-si, Jeollanam-do, South Korea. Live fish samples were transported to the Meat Science Laboratory, Chonnam National University, Gwangju, Korea, and killed within $30 \mathrm{~min}$ before manual filleting. Fish fillets were cut into cubic shape and all fish cubes from different fish were mixed together before dividing into $200 \mathrm{~g}$ per portion. Samples were kept at $-20^{\circ} \mathrm{C}$ under vacuum condition until used.

Chicken breast samples without skin ( $\approx 120 \mathrm{~g}$ per each) were ground after trimming out the connective tissue. Chicken mince was divided into $900 \mathrm{~g}$ per portion. All samples were kept under vacuum condition and frozen at $-20^{\circ} \mathrm{C}$ until used. MTG (TG-S) was obtained from the Ajinomoto Korea Inc. (Korea). Other chemicals were of analytical grade.

\section{Processing Procedures}

\section{Preparation of fish SP}

The frozen fish cubes were homogenized with de-ionized water (DI-water) at the ratio of fish: DI-water of 1:3 for $2 \mathrm{~min}$. The homogenate was centrifuged for $15 \mathrm{~min}$ at $1,000 \mathrm{~g}$ using a centrifuge (Beckman, J2-21, USA) before
Table 1. The formulation of no-fat sausage prepared from chicken mediated by MTG as affected by fish SP and STPP

\begin{tabular}{cccc}
\hline \hline \multirow{2}{*}{ Ingredients } & \multicolumn{3}{c}{ Treatments } \\
\cline { 2 - 4 } & Control Fish SP $(1 \%)$ STPP $(0.5 \%)$ \\
\hline Chicken breast mince & 60 & 60 & 60 \\
Ice & 15 & 15 & 15 \\
Hydrated water for CN:KF $^{1)}$ & 10 & 10 & 10 \\
Hydrated water for SPI $^{2}$ & 6 & 6 & 6 \\
SPI & 1.5 & 1.5 & 1.5 \\
CN+KF (1:1) & 1 & 1 & 1 \\
Salt & 1.3 & 1.3 & 1.3 \\
Cured blend & 0.25 & 0.25 & 0.25 \\
Corn syrup & 1 & 1 & 1 \\
Sodium erythobate & 0.05 & 0.05 & 0.05 \\
Sugar & 1 & 1 & 1 \\
Spices & 1 & 1 & 1 \\
Whole fat dried milk & 1 & 1 & 1 \\
MTG & 0.5 & 0.5 & 0.5 \\
Normal SP & 0 & 1 & 0 \\
STPP & 0 & 0 & 0.5 \\
\hline Total & 100 & 101 & 100.5 \\
\hline
\end{tabular}

${ }^{1)} \mathrm{CN}$ and $\mathrm{KF}$, Carageenan and konjac flour, respectively. The ratio between $\mathrm{CN}: \mathrm{KF}$ mixture was $1: 1$. The mixture was mixed with water at the ratio of mixture: water of 1:10 by blending water before adding mixture; ${ }^{2}$ SPI, Soy Protein Isolate; SPI was hydrated with water at the ratio of SPI:water of $1: 4 ;{ }^{3}$ STPP, Sodium tripolyphosphate.

collecting the supernatant. The supernatant was kept in freezer $\left(-70^{\circ} \mathrm{C}\right)$ overnight. Then, the frozen solution was lyophilized at temperature of about $-50^{\circ} \mathrm{C}$ under the vacuum pressure (7 mmtorr) to obtain SP powder using freezedryer (IlShin Lab Co, Ltd., Korea).

\section{Preparation of no-fat chicken sausages}

Chicken breast mince was chopped with ice and salt, and temperature was controlled below $12^{\circ} \mathrm{C}$ (Table 1). The meat batter was stuffed into the polyvinylidene chloride (PVDC) casing (diameter of $2.5 \mathrm{~cm}$ ) using stuffer before tightening with cotton rope to obtain the sausages with the length of about $15 \mathrm{~cm}$. All samples were incubated at $4^{\circ} \mathrm{C}$ for $6 \mathrm{~h}$ to allow MTG interact with other non-meat proteins. The incubated sausages were heated in a water bath controlled the temperature at $75^{\circ} \mathrm{C}$ for $30 \mathrm{~min}$. The cooked sausages were chilled immediately in an ice water and kept at $4^{\circ} \mathrm{C}$ overnight.

\section{Quality evaluation of no-fat chicken sausage}

\section{Proximate analysis}

Moisture content was determined by the oven-drying, while the crude fat was determined by soxhlet extraction 
using the diethyl ether as the solvent. Crude protein was estimated by the Kjeldahl method. Those chemical compositions were analyzed according to the AOAC methods (AOAC, 2000).

\section{Cooking yield}

The weight of sausage after cooking was recorded and calculated the cooking yield relative to the original weight (sample weight before cooking) and expressed as percentage.

\section{$\mathrm{pH}$}

The $\mathrm{pH}$ value of sausage was measured as solid state at the room temperature using the $\mathrm{pH}$ meter (MP120, MettlerToledo, Switzerland). Mean value was calculated based on 3 replications.

\section{Expressible moisture}

Chicken sausage samples were cut into cubic shape with the weight of $1.5 \mathrm{~g}$. Samples were wrapped with 3 layers of filter paper (Whatmann No.3) before loading into the centrifuge tube $(50 \mathrm{~mL})$. All samples were centrifuged at $1,000 \mathrm{~g}$ for $15 \mathrm{~min}$ at room temperature using centrifuge (Vision Science, Korea). The expressible moisture was calculated from the ratio of moisture absorbed by filter papers and weight of sample, and expressed as percentage.

\section{Color}

Color values of sausage were measured using the Hunter color meter (Color reader, CR-10, Minolta, Japan). The color values were reported as Hunter $L, a$ and $b$.

\section{Texture profile analysis}

Chicken sausages were cored using puncturing apparatus with cylindrical shape. The diameter and the length were 12.5 and $13 \mathrm{~mm}$, respectively. The textural profile of chicken sausage samples was analyzed using the Instron Universal (Instron model 3344, USA). The compression test was applied for 2 bite cycles with the compression of $75 \%$ of sample height using the $500 \mathrm{~N}$ load cell at the cross-speed of $300 \mathrm{~mm} / \mathrm{min}$. Texture profile analysis was reported as the hardness, springiness, cohesiveness, adhesiveness, gumminess, and chewiness.

\section{Sensory evaluation}

The sensory evaluation of sausage was conducted by the hedonic test. Sausage samples were cut into the same size with the thickness approximately of $5 \mathrm{~mm}$ before packing into vacuum condition. All samples were boiled for $5 \mathrm{~min}$.
The sensory attributes including flavor, color, texture, taste, and overall acceptance as a hedonic test were evaluated based on the 8-point hedonic test using the untrained panelists.

\section{Statistical analysis}

A significant difference at confidential level $(p \leq 0.05)$ was considered for mean values, which was based on the ANOVA analysis using the PASW statistics 18 (SPSS Inc., USA).

\section{Results and Discussion}

\section{Proximate analysis}

The fat content of all samples were not different and the observed fat contents were less than $0.5 \%$, considering as no-fat meat products (Chin et al., 1999), as USDA regulation (1982) stated. Thus, the sausage products developed in this study were classified as no-fat products. The chemical compositions of no-fat sausages are shown in Table 2 . No differences in moisture content were observed ( $p>$ $0.05)$. This suggested that the moisture content in SP solution was removed almost completely after lyophilization. Then, adding of SP in low amount did not affect the content of moisture in cooked sausage. The similar moisture contents in duck sausages were also reported, regardless the addition of cereal flour (Yang et al., 2009). The protein contents in all sausage samples were observed to be similar. Thus, this suggested that incorporation of 1\% SP did not affect the protein content although SP is carried a source of nitrogen, which may be detected by protein determination by Kjeldahl method. In addition, the different textural properties and sensory scoring would not be caused by the different protein content.

\section{Physico-chemical properties}

\section{Cooking yield}

The no-fat chicken sausages mediated by MTG were

Table 2. Chemical composition by proximate analysis of nofat sausage prepared from chicken mediated by MTG as affected by fish SP and STPP

\begin{tabular}{cccc}
\hline \hline Chemical & \multicolumn{3}{c}{ Treatments } \\
\cline { 2 - 4 } compositions & Control & Fish SP (1\%) & STPP $(0.5 \%)$ \\
\hline Moisture (\%) & $77.38 \pm 0.06$ & $77.34 \pm 0.72$ & $78.14 \pm 0.65$ \\
Fat content (\%) & $0.19 \pm 0.19$ & $0.52 \pm 0.18$ & $0.32 \pm 0.15$ \\
Protein & $14.04 \pm 0.48$ & $14.85 \pm 0.60$ & $13.89 \pm 0.87$ \\
content (\%) & & & \\
\hline
\end{tabular}

Mean \pm SE was calculated based on 2 replications. 
manufactured and the effect of fish SP (1\%) on the qualities was investigated as shown in Table 3. The STPP at $0.5 \%$ was used as a positive control due to the maximum value allowable (USDA, 1982). The cooking yield values of sausages were not different $(p>0.05)$ among the treatments, as shown in Table 3. This result suggested that addition of fish SP played neither positive nor negative effects on the cooking yield of the protein gel in the model of "no-fat chicken sausage". It has been reported previously that fish SP could hold more water in chicken protein gel mediated by MTG when other non-meat proteins were absence (Hemung and Chin, 2014). The contradictory results may be due to the action of non-meat protein ingredients, such as, soy protein and milk proteins (Table 1). These ingredients have been reported to hold more water, resulting in an improving cooking yield of food protein gel (Pietrasik et al., 2007). Since high cooking yield was obtained already, further improvement was not found by addition of fish SP or STPP.

\section{$\mathrm{pH}$}

The $\mathrm{pH}$ values of sausages were increased when fish SP was added. In addition, highest $\mathrm{pH}$ was observed from sausage samples with STPP (Table 3). Such increased pH value might be due to the basic amino acids, presenting in lyophilized SP. This suggested that addition of non-meat protein would likely affect the $\mathrm{pH}$ of sausage. The $\mathrm{pH}$ value of duck sausage batter also increased with addition of cereal proteins (Yang et al., 2009). It can be seen that highest $\mathrm{pH}$ value of sausages was found when STPP was added because STPP is an alkaline phosphate in the solubilized form and also considered as the polyanion. This would explain why STPP could bring the $\mathrm{pH}$ of sausage to the highest value. Shahidi and Synowiecki (1997) also found that the $\mathrm{pH}$ value of meat products was increased upon addition of STPP.

\section{Expressible moisture}

The results of expressible moisture indicated how tight of the water molecules were bound to protein in sausages, as shown in Table 3. The data strongly indicated the differences in expressible moisture among treatments are different $(p \leq 0.05)$. This indicated that addition of SP into the sausage mixtures could bind more added water although the comparable cooking yield was observed (Table 3). Sausages added with STPP showed lowest expressible moisture. In previous studies, fish SP powder also showed the water holding capacity to the comparable to other nonmeat protein ingredients e.g., egg white protein, whey pro- tein, and soy protein (Yongsawatdigul and Hemung, 2010). STPP is an important ingredient to enhance the water holding capacity in meat products. The mechanism of increasing water holding capacity with the addition of STPP is based on the sequestering ability and also dissociating actomyosin (Trout and Schmidt, 1984). Since the chemical structure of STPP is classified as polyanion, it is capable to bind with positive charged groups in proteins (Steinhauer, 1983). In addition, the ionic strength effect of phosphate brought the $\mathrm{pH}$ of proteins away from their isoelectric points (pI), which provide more water absorption. It has been reported that the $\mathrm{pH}$ value of meat protein should be around $\mathrm{pH}$ 6-7 in order to obtain the maximal water binding (Shahidi and Synowiecki, 1997). Since the addition of STPP caused to the higher $\mathrm{pH}$ value than that with SP, the water holding capacity of samples with STPP would be higher than that with fish SP.

\section{Color}

The color values of no-fat sausages were measured and the results are shown in Table 4. The redness value (Hunter $a$ value) of sample with STPP was lower than that of the control sausages and those with fish SP $(p \leq 0.05)$. However, the lightness and yellowness values of all samples were not different $(p>0.05)$. It has been reported that there was a correlation between lightness and cooking yield of emulsion sausages (Serdaroglu, 2006). In addition, the cooking yield could be predicted by the lightness. Since the

Table 3. Physicochemical properties of no-fat sausage prepared from chicken mediated by MTG as affected by fish SP and STPP

\begin{tabular}{cccc}
\hline \hline Physical & \multicolumn{3}{c}{ Treatments } \\
\cline { 2 - 4 } properties & Control & Fish SP $(1 \%)$ & STPP $(0.5 \%)$ \\
\hline $\begin{array}{c}\text { Cooking yield } \\
(\%)\end{array}$ & $99.29 \pm 0.01$ & $99.64 \pm 0.01$ & $99.53 \pm 0.01$ \\
pH & $6.23 \pm 0.01^{\mathrm{c}}$ & $6.26 \pm 0.01^{\mathrm{b}}$ & $6.31 \pm 0.01^{\mathrm{a}}$ \\
$\begin{array}{c}\text { Expressible } \\
\text { moisture (\%) }\end{array}$ & $18.48 \pm 0.65^{\mathrm{a}}$ & $16.18 \pm 0.28^{\mathrm{b}}$ & $14.81 \pm 0.22^{\mathrm{c}}$ \\
\hline
\end{tabular}

Mean \pm SE was calculated based on 2 replications.

${ }^{\mathrm{a}-\mathrm{c}}$ Different letters in the same row are statistically different $(p \leq 0.05)$.

Table 4. Color values of no-fat sausage prepared from chicken mediated by MTG as affected by fish SP and STPP

\begin{tabular}{cccc}
\hline \hline \multirow{2}{*}{ Color values } & \multicolumn{3}{c}{ Treatments } \\
\cline { 2 - 4 } & Control & Fish SP $(1 \%)$ & STPP $(0.5 \%)$ \\
\hline Hunter $L$ & $80.8 \pm 0.34$ & $80.3 \pm 0.06$ & $80.1 \pm 0.08$ \\
Hunter $a$ & $8.0 \pm 0.01^{\mathrm{a}}$ & $7.7 \pm 0.11^{\mathrm{a}}$ & $7.5 \pm 0.07^{\mathrm{b}}$ \\
Hunter $b$ & $10.7 \pm 0.05$ & $11.2 \pm 0.22$ & $10.0 \pm 0.13$ \\
\hline
\end{tabular}

Mean \pm SE was calculated based on 2 replications with 5 measurements.

${ }^{a, b}$ Different letters in the same row are statistically different $(p \leq 0.05)$. 
cooking yields of our sausage samples were not different among the treatments with the similar lightness values, application of normal SP in the commercial products would likely be possible and might not affect the color perception, especially whiteness.

\section{Textural properties}

The textural properties of no-fat chicken sausages with SP, as compared to the control and those with STPP, are shown in Table 5. The hardness of no-fat sausages was improved about $37 \%$ by addition of SP, although MTG was added into all treatments. The similar results were also reported for chicken MP gel mediated by MTG (Hemung and Chin, 2014). Such improvement was from a reduction of thermal stability upon adding fish SP. Kim et al. (2005) found that SP could improve textural properties of surimi gel prepared with MTG. Our results in this study indicated that the textural properties of sausages were improved more by adding SP, although they were already enhanced by MTG. The springiness, gumminess, chewiness, cohesiveness, and adhesiveness of chicken sausages were not affected by SP addition.

It can be clearly seen that the sausage samples containing STPP showed the highest textural properties, such as hardness, springiness, and chewiness (Table 5). Ruusunen et al. (2003) reported that addition of phosphate improved the textural properties and water holding capacity of protein gel at the salt level lower than $1.5 \%$. The mechanism of STPP to improve textural properties has been explained by the controlling $\mathrm{pH}$, which extracted more protein to generate the functional properties. In addition, high binding ability to water of STPP resulted in the high juiciness, which was preferred by the consumer. Therefore, STPP has been used as the important ingredient to improve the

Table 5. Texture profile analysis of no-fat sausage prepared from chicken mediated by MTG as affected by fish SP and STPP

\begin{tabular}{cccc}
\hline \hline Physical & \multicolumn{3}{c}{ Sample } \\
\cline { 2 - 4 } properties & Control & Fish SP $(1 \%)$ & STPP $(0.5 \%)$ \\
\hline Hardness & $1838 \pm 22^{\mathrm{c}}$ & $2527 \pm 244^{\mathrm{b}}$ & $4356 \pm 136^{\mathrm{a}}$ \\
Springiness & $5.36 \pm 0.49^{\mathrm{ab}}$ & $4.6 \pm 0.51^{\mathrm{b}}$ & $6.36 \pm 0.02^{\mathrm{a}}$ \\
Gumminess & $13.65 \pm 0.4^{\mathrm{ns}}$ & $23.53 \pm 5.41^{\mathrm{ns}}$ & $53.43 \pm 25.89^{\mathrm{ns}}$ \\
Chewiness & $73.56 \pm 3.4^{\mathrm{b}}$ & $105.47 \pm 10.14^{\mathrm{b}}$ & $247.70 \pm 22.25^{\mathrm{a}}$ \\
Cohesiveness & $0.0075 \pm$ & $0.0093 \pm$ & $0.0089 \pm$ \\
& $0.0004^{\mathrm{ns}}$ & $0.0013^{\mathrm{ns}}$ & $0.0005^{\mathrm{ns}}$ \\
Adhesiveness & $-0.0042 \pm$ & $-0.0075 \pm$ & $-0.0059 \pm$ \\
& $0.0001^{\mathrm{ns}}$ & $0.0024^{\mathrm{ns}}$ & $0.0013^{\mathrm{ns}}$ \\
\hline
\end{tabular}

Mean \pm SD was calculated based on 2 replications.

Mean value from 1 replication was from 8 measurements.

${ }^{\mathrm{a}-\mathrm{d}}$ Different superscripts in the same row are different $(p \leq 0.05)$. functional properties of the cured meat products. That is why STPP was selected as a reference in this study. However, the consumers tend to prefer to take the meat products with low or free phosphate residues for their health concern. This is because phosphate might play a negative effect on the balance of calcium, iron, and magnesium in the body, resulting in the risk for bone diseases (Shahidi and Synowiecki, 1997). Therefore, the way to reduce or eliminate phosphate from meat products would be developed. It has been reported that high salt and MTG could be used to produce the desirable quality of phosphate-free restructured pork shoulder (Dimitrakopoulou et al., 2005). Based on the textural properties, addition of fish SP in the no-fat sausage could improve the textural properties, although they were not comparable to those with addition of STPP. However, application of fish SP for the synergistic effect in order to reduce the STPP with maintaining the desirable textural properties in chicken sausages would be possible. This would be the potential to substitute of phosphate in no-fat sausages, which is considered as healthy food products.

\section{Sensory evaluation}

The perception of consumer regarding the quality attributes evaluated by hedonic test was performed as the results shown in Table 6. The flavor of the control sample was accepted at the score higher than $50 \%$ (5.57 of 8). This suggested that the no-fat chicken sausages would likely be accepted by the consumers. The results were in agreement with Tseng et al. (2000), who reported that the acceptable flavor of low-salt chicken meat-ball was obtained when MTG was added. In addition, low-salt restructured pork shoulder was also accepted at the score over 5 from the 9 points hedonic test (Dimitrakopoulou et al., 2005). These results also indicated that addition of fish SP did not affect the flavor perception for the consumers.

The color perception scores of panelists toward the tes-

Table 6. Sensory evaluation of no-fat sausage prepared from chicken mediated by MTG as affected by fish SP and STPP

\begin{tabular}{cccc}
\hline \hline Sensory & \multicolumn{3}{c}{ Treatments } \\
\cline { 2 - 4 } attributes & Control & Fish SP $(1 \%)$ & STPP $(0.5 \%)$ \\
\hline Flavor & $5.57 \pm 0.2$ & $5.57 \pm 0.2$ & $5.57 \pm 0.2$ \\
Color & $5.21 \pm 0.1^{\mathrm{a}}$ & $5.43 \pm 0.0^{\mathrm{ab}}$ & $5.64 \pm 0.1^{\mathrm{a}}$ \\
Texture & $5.00 \pm 0.2^{\mathrm{b}}$ & $5.43 \pm 0.2^{\mathrm{b}}$ & $6.86 \pm 0.2^{\mathrm{a}}$ \\
Taste & $5.93 \pm 0.1^{\mathrm{b}}$ & $5.93 \pm 0.1^{\mathrm{b}}$ & $6.57 \pm 0.0^{\mathrm{a}}$ \\
Overall & $5.61 \pm 0.2^{\mathrm{b}}$ & $5.50 \pm 0.1^{\mathrm{b}}$ & $6.43 \pm 0.2^{\mathrm{a}}$ \\
\hline
\end{tabular}

Mean \pm SE was calculated based on 2 replications.

${ }^{\mathrm{a}, \mathrm{b}}$ Different letters in the same row are statistically different $(p \leq 0.05)$. 
ted sausages were different $(p \leq 0.05)$. Sausage samples with STPP had higher score, as compared to those of control and fish SP. The different scores might be due to the reduction of redness of sample with STPP as evidenced by color measurement. The texture of samples was clearly distinguished by the panelists, as the score was clearly different. The texture of sausage samples with STPP was the most accepted sample, corresponding with the highest hardness (Table 5). This suggested that an increase in hardness for 2.37 fold could be detected by the sensorial perception of the consumers. In addition, an increase in sensorial score of sausage with SP regarding the texture was not observed, although the textural properties were improved (Table 5). The taste and overall acceptance of the samples with STPP was highest when compared to the others. These results suggested that the texture of sample plays an important factor influencing the sensorial perception of consumer toward the sausage products. Based on the sensory evaluation, the complete substitution of STPP by fish SP might not be acceptable, although it could improve the textural properties and other characteristics. Therefore, partial substitution would be the alternative way to reduce the STPP in no-fat chicken sausage.

\section{Conclusion}

The no-fat chicken sausages mediated by MTG could be manufactured successfully. Addition of fish SP (1\%) resulted in an increase of the water holding capacity of products as well as improvement of textural properties, especially hardness. The color values of control sausage were not affected by addition of fish SP. A reduction of redness alone was found when $0.5 \%$ STPP was added. Addition of SP alone did not increase sensory score as did by STPP. Thus, partial substitution of STPP with fish SP could be possible to reduce phosphate in no-fat chicken sausages although the complete substitution might not be feasible.

\section{Adknowledgements}

This study was financially supported by Chonnam National University, 2014.

\section{References}

1. Ahhmed, A. M., Kawahara, S., Ohta, K., Kakade, K., Soeda, T., and Muguruma, M. (2007) Differentiation in improvements of gel strength in chicken and beef sausages induced by transglutaminase. Meat Sci. 76,455-462.
2. Ahhmed, A. M., Nasu, T., Huy, D. Q., Tomisaka, Y., Kawahara, S., and Muguruma, M (2009). Effect of microbial transglutaminase on the natural actomyosin cross-linking in chicken and beef. Meat Sci. 82, 170-178.

3. Ando, H., Adachi, M., Umeda, K., Matsuura, M., Nonaka, M., Uchio, R., Tanaka, H., and Motoki, M (1989). Purification and characteristics of novel transglutaminase derived from microorganisms. Agric. Biol. Chem. 53, 2613-2617.

4. Association of official analytical chemists. 2000. Meat and meat products-Method 950.46. 991.36. Maryland, USA. pp. $1,3,7-8$.

5. Chin, K. B., Keeton, J. T., Longnecker, M. T., and Lamkey, J. W. (1999) Utilization of soy protein isolate and konjac blends in a low-fat bologna (model system). Meat Sci. 53, 45-57.

6. Dimitrakopoulou, M. A., Ambrosiadis, J. A., Zetou, F. K., and Bloukas, J. G. (2005) Effect of salt and transglutaminase (TG) level and processing conditions on quality characteristics of phosphate-free, cooked, restructured pork shoulder. Meat Sci. 70, 743-749.

7. Folk, J. E. (1980) Transglutaminase. Ann. Rev. Biochem. 49, 517-531.

8. Go, W. C. and Hwang, M. S. (1995) Contribution of milkfish sarcoplasmic protein to the thermal gelation of mofibrillar protein. Fish Sci. 61, 75-78.

9. Hemung, B. and Chin, K. B. (2013) Effects of fish sarcoplasmic proteins on the properties of myofibrillar protein mediated by microbial transglutaminase. LWT-Food Sci. Technol. 53, 184-190.

10. Hemung, B. and Chin, K. B. (2014) Effect of pH-treated fish sarcoplasmic proteins on the functional properties of chicken myofibrillar protein gel mediated by microbial tranglutaminase. Korean J. Food Sci. An. 34, 1-9.

11. Hong, G. P. and Chin, K. B. (2010) Effect of microbial transglutaminase and sodium alginate on cold set gelation of porcine myofibrillar protein with various salt levels. Food Hydrocolloid. 24, 444-451.

12. Jafarpour, A. and Gorczyca, E. M. (2009) Characteristics of sarcoplasmic proteins and their interactions with surimi and kamaboko gel. J. Food Sci. 74, 16-22.

13. Kim, Y. S., Yongsawatdigul, J., Park, J. W., and Thawornchinsombut, S. (2005) Characteristics of sarcoplasmic proteins and their interaction with myofibrillar proteins. J. Food Biochem. 29:517-31.

14. Lin, T. M., Park, J. W., and Morrissey, M. T. (1995) Recovered proteins and reconditioned water from surimi processing waste. J. Food Sci. 50, 4-9.

15. Pietrasik, Z., Jarmoluk, A., and Shand, P. J. (2007) Effect of non meat proteins on hydration and textural properties of pork meat gels enhanced with microbial transglutaminase. LWTFood Sci. Technol. 40, 915-920.

16. Ramirez-Suarez, J. C. and Xiong, Y. L. (2003) Effect of transglutaminase-induced cross-linking on gelation of myofibrillar/soy protein mixtures. Meat Sci. 65, 899-907.

17. Ruusunen, M., Vainionpaa, J., Puolanne, E., Lyly, M., Lahteenmaki, L., Niemisto, M., and Ahvenainen, R. (2003) Physical and sensory properties of low-salt phosphate-free frank- 
furters composed with various ingredients. Meat Sci. 63, 916.

18. Serdaroglu, M. (2006) The characteristics of beef patties containing different levels of fat and oat flour. Inter. J. Food Sci. Tech. 41,147-153.

19. Shahidi, F. and Synowiecki, J. (1997) Protein hydrolizates from seal meat as phosphate alternatives in food processing applications. Food Chem. 60, 29-32.

20. Steinhauer, J. E. (1983) Food phosphates for use in the meat, poultry and seafood industry. Dairy Food Sanitation. 3, 244247.

21. Trout, G. R. and Schmidt, G. R. (1984) Effect of phosphate type and concentration, salt level and method of preparation on binding in restructured beef rolls. J. Food Sci. 49, 687694.
22. Tseng, T. F., Liu, D. C., and Chen, M. T. (2000) Evaluation of transglutaminase on the quality of low-salt chicken meatballs. Meat Sci. 55, 427-431.

23. United States Department of Agriculture (USDA). (1982) Meat and poultry products: phosphates and sodium hydroxide. Federal Registration, 47, 10779.

24. Yang, H. S., Ali, M. S., Jeong, J. Y., Moon, S. H., Hwang, Y. H., Park, G. B., and Joo, S. T. (2009) Properties of duck meat sausages supplemented with cereal flours. Poultry Sci. 88, 1452-1458.

25. Yongsawatdigul, J. and Hemung, B. (2010) Structural changes and functional properties of threadfin bream sarcoplasmic proteins subjected to $\mathrm{pH}$-shifting treatments and lyophilization. J. Food Sci. 75, C251-257. 